\title{
The Influence of the Electronic Currency on the Conventional Monetary Theory
}

\author{
Gao Ruiqiong \& Feng Junwen \\ School of Economics \& Management, NJUST, Nanjing, Jiangsu, China
}

\begin{abstract}
With the increasingly development of technology, new things related to the Internet are emerging. Internet finance is such a new type that comes from the close combination of traditional finance and modern information network technology. Currency is the core element in the financial market and business activities. Likewise, currency electronization is the key to internet finance. With its convenience, high speed and efficiency, electronic currency has become a part of our daily life. Meanwhile, it affects the money supply and demand. The traditional monetary theory is facing challenges. This article focuses on the evolution of electronic currency and its influence on the traditional monetary theory.
\end{abstract}

KEYWORD: electronic currency; Money Multiplier; Velocity of circulation; Monetary theory; Monetary policy

Various sorts of industries are comprehensively and profoundly influenced by information technology, including financial industry, the combination of which has brought in the Internet finance and the changes in currency form, followed by virtualized, informational zed, digitalized electronic currency. Thanks to the internet, the internet finance and electronic have break up the limitations of time and space, besides, the expenditure and labor force on the printing, circulation, transporting and counting have been saved and space cost has been reduced. At the same time, however, electronic currency has also brought new challenges to the traditional monetary theory.

\section{THE DEFINITION AND FEATURE OF ELECTRONIC CURRENCY}

According to the Basel Committee, electronic currency refers to the value-storing and prepaying mechanism by selling terminals, different electronic equipments on public internet in retail payment mechanism. In fact, electronic currency is the informational zed data between storage and computer terminal, which digitalizes the paper currency and becomes the newest form. At present stage, a variety of electronic equipment such as debit card is usually acted as media of the use of electronic currency. Electronic currency is a kind of credit currency, which is constituted by binary data and digital signature on the basis of specific hardware and software system and internet. Issuer is not only the central bank, but also the financial institutions and even enterprise and public institutions, who can issue in a small scope. Different from paper currency, electronic currency adopts encryption algorithm, certification system and digital signature instead of anti-fake label to ensure its safety. Moreover, electronic currency can be circulated around globe without limitation.

\section{CURRENT RESEARCH SITUATION OF ELECTRONIC CURRENCY}

In recent years, the extensive application of electronic currency has aroused hot research and discussion on its theoretical influence in all walks of life, including the influence on the velocity of circulation and supply theory.

The influence on circulation velocity: Wang Lubin(1999), BIS(1996, 2000, 2001, 2004)and The Group of Computer Experts(1996) believe that electronic currency speeds up the circulation. The traditional currency theory, however, holds the opinion that the velocity of circulation is stable or regularly changed. The appearance of electronic currency has smashed this statement and makes the velocity of circulation change randomly (Yinlong, 2000). Combined with our practical supply of 
currency, Pu Chengyi(2002) thinks the velocity of currency circulation is changed in $\mathrm{V}$ form after the circulation of electronic currency. At the beginning, the velocity of circulation is lower by its reduction, but in the latter period, the velocity is higher by its rapid development. Zhou Guangyou(2006) makes an analysis on the influencing factors of velocity of currency and names out the following ones: cash ratio $\left(\frac{M_{0}}{M_{1}}\right)$; flexibility of currency $\operatorname{supply}\left(\frac{M_{1}}{M_{2}}\right)$; degree of finance electronization $\left(\frac{M_{2}-M_{0}}{M_{2}}\right)$; degree of currency electronization $\left(\frac{F A}{M_{1}}\right)$. The analysis of effect on traditional currency brought by electronic currency shows that the velocity of currency circulation is loweredwith the co-function of alternative accelerating effect and alternative transferring effect.

The influence on currency supply brought by electronic currency: Deng Qingchen(2009) makes a brand-new deduction on currency supply after electronic currency came out, which concludes that electronic currency exerts no influence on currency supply, and to effectively control the currency supply, central bank is supposed to regulate required reserves and initial discount rate of electronic currency. Some believe electronic currency enhances the endogeneityof currency supply (Zhou Guangyou and Qiu Changrong 2005). Zhou Guangyou builds up a measuring mode with currency ratio and electronic currency alternation rate as the independent variable, which reflects the relation between electronic currency and currency supply, and electronic currency exerts a strong alternative effect on traditional currency. Friedman(2000) thinks electronic currency has a profound influence on currency multiplier and basic currency and then influence the currency supply.

\section{THE INFLUENCE ON CURRENCY MULTIPLIER}

Currency multiplier refers to the credit expanding multiple produced by derivative deposit by creating deposit money function of commercial banks on the basis of basic currency, which is the expanding multiple of currency supply. It is required to deduce the relation among basic currency, reserves and currency supply in formula in order to analyze the influence of electronic currency on currency multiplier.

Currency supply volume is the currency balance circulated outside of bank system and the sum of deposit balance belongs to residents or enterprises in commercial bank, which can be expressed in such formula:

$$
M_{\mathrm{s}}=C+D
$$

$M_{\mathrm{s}}$ is the currency supply volume, currency balance is C, and deposit balance is D

Basic currency is the sum of required reserves and currency balance, which can be expressed in such formula:

$$
\mathrm{B}=R+C
$$

Basic currency is B, reserves balance is R. The formula of currency multiplier is expressed like this:

$$
\mathrm{m}=\frac{M_{\mathrm{s}}}{B}=\frac{C+D}{R+C}=\frac{\frac{C}{D}+1}{\frac{R}{D}+\frac{C}{D}}
$$

$\mathrm{m}$ refers to the currency multiplier, $\frac{C}{D}$ called currency ratio(cash-deposit ratio) and $\frac{R}{D}$ is reserve ratio(reserves-deposit ratio), $\mathrm{m}$ is determined by these two ratio.

Formula (3.1), (3.2), (3.3) is the deductive formula of traditional currency theory on currency multiplier, excluding electronic currency. The change in formula of currency multiplier with electronic currency is discussed, supposing electronic currency balance as E.

(3.1) is changed into:

$$
M_{\mathrm{s}}=C^{\prime}+E+D^{\prime}
$$

Here, the sum relatively refers to the cash balance and deposit balance after the appearance of electronic currency. (3) is changed into:

$$
\mathrm{m}^{\prime}=\frac{C^{\prime}+E+D^{\prime}}{R^{\prime}+C^{\prime}}=\frac{\frac{C^{\prime}+E}{D^{\prime}}+1}{\frac{R^{\prime}}{D^{\prime}}+\frac{C^{\prime}}{D^{\prime}}}
$$

The two formulas of currency multiplier will be compared in the following part because cash or deposit may be replaced by electronic currency.

The first case is cash replaced by electronic currency, without influencing deposit, namely, cash plus electronic currency is the total cash before electronic currency come out. The formula is $\mathrm{C}=\mathrm{D}+\mathrm{E}, \mathrm{D}=D^{\prime}$. Here, $\frac{C^{\prime}}{D^{\prime}}<\frac{C}{D}$ refers to the decrease of currency ratio, then $\frac{C^{\prime}+E}{D^{\prime}}=\frac{C}{D} \cdot \frac{R^{\prime}}{D^{\prime}}<\frac{R}{D}$ refers deposit amount without any influence. It can be concluded that $\mathrm{m}$ will get larger. 
The second case is deposit replaced by electronic currency without change in cash amount, namely, deposit plus electronic currency is the deposit amount before electronic currency came out. The formula is $C=C^{\prime} . E+D^{\prime}=D$. So far, a majority of counties have not levied required reserves to electronic currency, so the electronic currency issued by producer does not need to pay required reserves. It can be concluded that currency multiplier $m$ will get larger because the reduction of required reserves.

\section{THE INFLUENCE OF ELECTRONIC CURRENCY ON DEMAND THEORY}

The influence of electronic currency on traditional theory should be analyzed with several classic demand theories_-Fisher equation, Keynesians currency demand theory and Friedman currency demand theory.

\subsection{The Influence on Fisher Equation}

Fisher Equation:

$$
\mathrm{MV}=\mathrm{PY}
$$

$\mathrm{M}$ is the amount of demanding currency, $\mathrm{V}$ is the velocity of currency circulation, $\mathrm{P}$ is price, $\mathrm{Y}$ is the trade number of commodity, PY is the nominal revenue. In traditional currency mode, $\mathrm{V}$ is a constant, so $M$ and $P Y$ is changed in the same direction and proportion.

After electronic currency came out, the time used for withdrawing money and other transaction is greatly shortened and the velocity is fastened. In the process of getting faster, it is a variable instead of a constant. It can be concluded easily that adding electronic currency only can make $\mathrm{V}$ get large and $\mathrm{M}$ small.

\subsection{The Influence on Keynesians Currency Demand Theory}

Keynesians currency demand theory is also called liquidity preference theory. He made an analysis on currency demand from the perspective of capital liquidity on the basis of Cambridge school. In his theory, the motives of people holding currency are: transaction motive, precautionary motive and speculative motive. The currency demand produced by transaction motive, precautionary motive is called trading currency demand, expressed by $\mathrm{L}_{1}, \mathrm{~L}_{2}$ refers to speculative motive. The formula of Keynesians currency demand theory is :

$$
\mathrm{M}=\mathrm{M} 1+\mathrm{M} 2=\mathrm{L} 1(\mathrm{y})+\mathrm{L} 2(\mathrm{r})=\mathrm{ky}-\mathrm{hi}
$$

From above formula, it can be seen that the demand of cash transaction has a negative correlation with rate and positive correlation with revenue $y$ without electronic currency, and the related coefficient will not be easily changed.

However, the electronic currency meet people's demand for $L_{1}$, which leads to the decrease of the currency portion in revenue( $\mathrm{k}$ decrease). William and James made a research on transaction demand and added in three variables that are the cost of bank commute $\mathrm{F}$, the revenue of a certain period $\mathrm{X}$ and deposit of fixed rate I. As a result, he got the best cash holdings $C=\sqrt{2 F X / I}$, which reflected that the demand for cash had a positive correlation with cost in bank commute. After the electronic currency came out, people can use internet to do transactions, resulting in the reduction of $\mathrm{F}, \mathrm{C}$ and $\mathrm{L}_{1}$.

The change in $\mathrm{L}_{2}$ is mainly determined by rate. The return rate is different with different investment ways in the traditional currency market. However, after the electronic currency came out, the currency flexibility has been greatly enhanced and people can freely switch in various transactions, which caused the decrease in $\mathrm{L}_{1}$ fund. People hold an increasing amount of electronic currency for the demand of $\mathrm{L}_{2}$ and put them to the capital market with high return rate to enlarge $h$. The change in rate exerts a stronger influence on demand. It can be found that at the same time when electronic weaken the transaction motive and precaution motive; it fortifies the speculative motive's demand for currency.

\subsection{The Influence on Friedman Currency Demand Theory}

Friedman does not analyze the reason why people holding cash, andhe does not think the expected return rate of currency is zero, instead, he regards currency as a capital that changes with other expected return rate. He believes that currency, bond, stock and human wealth are the total amount of people's holding wealth. The demand function is:

$$
M=f\left(P, r b, r e, \frac{1}{p} \times \frac{d p}{d t}, W, Y, u\right)
$$

$\mathrm{M}$ refers to the currency demand, $\mathrm{P}$ is price, $r b$, re relatively refers to the expected return rate of bond and stock, $\frac{1}{p} \times \frac{d p}{d t}$ which is the expected change rate of price, $\mathrm{W}$ is the portion of non-human wealth in total wealth, $\mathrm{Y}$ refers to the permanent nominal revenue, $u$ refers to other factors. Dividing both sides of the above formula with price $\mathrm{p}$ and you can get the practical currency demand amount $\frac{M}{P}=f\left(r m, r b, r e, \frac{1}{p} \times \frac{d p}{d t}, W, Y, u\right)$. 
With the wide application of electronic currency, however, coping with currency liquidity does not need great holdings of currency and people can put the fund into the financial fund with higher return rate. In Friedman currency demand theory, the opportunity cost of cash holding including bond and expected return rate of stock ( $r b$ and $r e$ ), The higher $r b$ and $r e$ are, the higher the cost is. But the opportunity cost of financial fund(bond and stock) will be reduced by the application of electronic currency(the currency provides less transferring cost to financial fund), so people will put fund into financial fund with high return rate without any consideration. Therefore, in terms of Friedman currency demand currency, because of the emerging of electronic currency, the expected return rate on financial fund should be attached more importance and gain more effect considering demand.

The wide application of electronic currency has accelerated the velocity of currency circulation and reduced the transferring cost, which transferred and changed the importance on demand variables and the change in currency demand, expecting means. As for policy-makers, they are confronted with more complicated issues.

\section{THE INFLUENCE OF ELECTRONIC CURRENCY ON CHINA CURRENCY POLICY}

\subsection{The Influence on Policy-makers}

Central bank is the constitutor and executor of currency policy, the publisher of currency, and the specific financial institution restraining and regulating market, providing commercial bank with credit support and administration. However, the wide application of electronic currency has exerted some influence on the function of central bank.

First of all, the rapid development of electronic currency intensifies the competitiveness of currency issue. With the help of internet, electronic currency has broken the national boundaries of currency issue and currency issuers are in the same line. What's more, the application of electronic payment is increasing and it shakes the status of traditional currency. Moreover, the issuers of electronic currency may be the common financial institution or even non-financial institution. All these factors intensify the competitiveness of currency issue.

Then central bank is required to improve it administration by electronic currency. Internet itself is featured in activeness, instability and administration evasion. As a product of internet and traditional currency, electronic currency is confronted with some potential risks in its application, which requires central bank to take measures to improve its administration. For instance, establishing and perfecting corresponding laws and regulations to comply with the development of electronic currency and ensure a healthy legal environment for its application. At present, we only have the administrative regulations on some business such as E-bank, but no formal or comprehensive legal regulations on electronic currency. So it is urgent to strengthen administration in such aspects. Besides, central bank is supposed to establish the required reserves system of electronic currency. The demand for traditional currency is decreased because some cash and deposit are replaced by electronic currency which should be included into required reserves and establish a well-played required reserves system to fully implement currency policy.

\section{REFERENCES}

[1] BIS, 1996, Implications for Central Banks of the Development of Electronic Money. Basel: BIS.

[2] BIS and the Group of Computer Experts, 1996, Survey of Electronic Money.

[3] BCBS, Monetary 1998(51), Policy Implication of Digital Money. International Review of Social Science: 20-25.

[4] BIS, 2002, Survey of Electronic Money Developments. Basel: BIS,

[5] BIS, 2004, Survey of Electronic Money and Internet and Mobile Payment. Basel: BIS.

[6] Freedman Charles, 2000, "Monetary Policy Implementation: Past, Present and Future-Will the Advent of Electronic Money Lead to the Demise of Central Banking?" unpublished, Bank of Canada, June.

[7] Friedman M. \& Schwartz A., 1963, "A Monetary History of the United States: 1867-1960", New York, National Bureau of Economic Research..

[8] Friedman \& Benjamin M., 1999, "The Future of Monetary Policy: The Central Bank as an Army with Only a Signal Corps?" International Finance, November 321-338.

[9] Friedman \& Milton, 1959, "A Program for Monetary Stability", New York: Fordham University Press.

[10] Yin Long, 2000, "The influence of electronic currency on central bank". Financial Research, 11-12.

[11] Yin Long, 2003, "On internet finance theory-the development and influence of internet bank and electronic currency. Published by Southwestern University of Finance and Economics.

[12] Chen Yulu \& Bian Weihong, 2002, "Analysis on development of electronic currency and risks confronted by central bank". International Financial Research.

[13] Pu Chengyi, 2002, "The definition and features of digital cash and its influence on different strata and division of currency". Economist.

[14] Pu Chengyi, 2002, "The influence of digital cash on supply and circulation velocity of currency. Financial Research.

[15] Wang Lubin \& Zhou Hong, 1999, "Electronic currency and financial risk prevention". China Finance.

[16] Wang Lubin \& Zhou Hong, 1999, "A new kind of payment means-electronic currency". Finance Electronization.

[17] Wang Lubin, 1999, "On electronic currency and currency policy". Financial Research.

[18] Deng Qingchen, 2009, "The deduction on influence of electronic currency on currency supply". Xiang Chao.

[19] Zhou Guangyou \& Qiu Changrong, 2005, "Argument and enlightenment on conduction mechanism of currency policy”. Finance and Science. 17-21. 